\title{
Pengaruh Perendaman Larva Ikan Pterapogon kauderni dengan Hormon 17a-Methyltestosteron Menggunakan Dosis yang Berbeda terhadap Rasio Kelamin Jantan
}

\author{
Muhammad Safir $^{1 \star}$, Samliok Ndobe ${ }^{2}$, Madinawati ${ }^{3}$, \\ Septina Fifi Mangitung ${ }^{4}$, Novalina Serdiati ${ }^{5}$, dan Moh. Ryaldi ${ }^{6}$ \\ 1,2,3,4 Staf Pengajar Program Studi Akuakultur, Jurusan Perikanan dan Kelautan \\ Fakultas Peternakan dan Perikanan, Universitas Tadulako \\ 5,6 Mahasiswa Program Studi Akuakultur, Jurusan Perikanan dan Kelautan \\ Fakultas Peternakan dan Perikanan, Universitas Tadulako \\ ${ }^{1}$ Email: muhammadsafir@untad.ac.id \\ 2 Email: samliok.ndobe@untad.ac.id \\ 3 Email: madinawati@untad.ac.id \\ ${ }^{4}$ Email: fifimangitung@untad.ac.id \\ ${ }^{5}$ Email: novalinaserdiati@untad.ac.id \\ 6.Email: mohryaldi15@gmail.com
}

*Penulis korespondensi: muhammadsafir@untad.ac.id

\begin{abstract}
Banggai cardinalfish (Pterapogon kauderni) is one of the endemic ornamental fish from Central Sulawesi. In its spawning, the male parent will incubate the eggs until they enter the juvenile phase. Moreover, the number of male broodstock in the wildlife is minimal, making this the limiting factor in increasing P. kauderni. The aim of the study was to obtain the best dose of the 17a-methyltestosterone (17a-MT) hormone in producing the male sex ratio of P.kaudemi. This study used a completely randomized design by with four treatments of $17 \alpha-M T$, such as $0 \mathrm{mg} / \mathrm{L}$; $2 \mathrm{mg} / \mathrm{L} ; 4 \mathrm{mg} / \mathrm{L}$, and $6 \mathrm{mg} / \mathrm{L}$ by immersion method. Each treatment had four replications. The results showed that the 17a-MT hormone did not affect the daily growth rate of $P$. kauderni $(P>0.05)$. The increase of biomass and survival rate were lower in $6 \mathrm{mg} / \mathrm{L}$ water; while the highest male sex ratio of $P$. kauderni, $91.67 \%$, at $2 \mathrm{mg} / \mathrm{L}$ water.
\end{abstract}

Keywords: Endemic, Hormone Immersion, Male Sex Ratio, Pterapogon kauderni, Sex Reversal

\begin{abstract}
ABSTRAK
Banggai cardinalfish (Pterapogon kauderni) adalah salah satu ikan hias endemik perairan Sulawesi Tengah. Dalam proses pemijahannya, induk jantan akan mengerami telur hingga memasuki fase juvenil. Kondisi tersebut (lamanya masa pengeraman) tentunya akan menghambat peningkatan populasi ikan $P$. kauderni dengan target jumlah dalam waktu tertentu terlebih jumlah induk jantan yang terbatas. Penelitian bertujuan untuk mendapatkan dosis hormon 17amethyltestosteron (17a-MT) terbaik dalam menghasilkan rasio kelamin jantan ikan $P$. kauderni yang tinggi. Penelitian didesain menggunakan rancangan acak lengkap dengan mengujikan empat perlakuan dosis $17 \alpha-M T$ meliputi $0 \mathrm{mg} / \mathrm{L} ; 2$ $\mathrm{mg} / \mathrm{L} ; 4 \mathrm{mg} / \mathrm{L}$ dan $6 \mathrm{mg} / \mathrm{L}$ air yang diterapkan melalui metode perendaman selama 4 jam. Setiap perlakuan dilakukan 4 kali ulangan. Hasil perlakuan perendaman larva dengan hormon 17a-MT pada dosis berbeda tidak berpengaruh terhadap laju pertumbuhan harian ikan $P$. kauderni $(P>0,05)$. Pertambahan biomasa dan kelangsungan hidup lebih rendah pada perlakuan dosis $6 \mathrm{mg} / \mathrm{L}$ air. Rasio kelamin jantan ikan $P$. kauderni tertinggi terjadi pada perlakuan dosis $2 \mathrm{mg} / \mathrm{L}$ air yakni sebesar $91,67 \%$.
\end{abstract}

Kata kunci: Endemik, Perendaman Hormon, Pterapogon kauderni, Rasio Kelamin Jantan, Seks Reversal 


\section{Pendahuluan}

Banggai cardinalfish (Pterapogon kauderni) adalah salah satu ikan hias endemik perairan Sulawesi Tengah (Ndobe et al., 2013a; Ndobe et al., 2013b). Tampilan dan tingkah laku yang unik menjadikan ikan ini digemari oleh banyak pecinta ikan hias baik nasional maupun internasional (Sugama, 2008; Ndobe et al., 2013b; Carlos et al., 2014). Guna mengantisipasi terjadinya kepunahan ikan $P$. kaudermi di alam akibat eksploitasi yang berlebih maka pemerintah melakukan pengaturan penangkapan secara terbatas berdasarkan tempat (di perairan Kepulauan Banggai, Sulawesi Tengah), dan waktu penangkapan (bulan Februari sampai Maret, dan Oktober sampai November). Aturan tersebut tertuang dalam Keputusan Menteri Kelautan dan Perikanan No. 49/KEPMENKP/2018.

Berdasarkan uraian diatas, upaya yang dapat dilakukan agar ikan ini tetap tersedia dipasaran, yakni melakukan kegiatan budidaya baik secara insitu (pada lokasi dimana ikan ini didapatkan seperti yang dilakukan oleh Balai Pelatihan Budidaya dan Konservasi Laut (LINI foundation) di Banggai Laut), maupun eksitu di luar dari sumber ikan ini diperoleh (Gunawan et al., 2010). Secara umum, dalam upaya peningkatan populasinya, keberadaan ikan $P$. kauderni berkelamin jantan menjadi salah satu faktor penting. Hal tersebut disebabkan ikan $P$. kauderni jantan memegang peranan penting dalam proses pemijahan (perkembangan telur menjadi larva) yakni telur yang telah dibuahinya akan dierami di dalam mulut selama kurang lebih 30 hari hingga memasuki fase juvenile (Gunawan et al., 2010; Ndobe et al., 2013a; Ndobe et al., 2013b). Pada kondisi ini, tentunya ikan $P$. kauderni induk jantan tidak menerima asupan nutrien dari pakan seperti yang terjadi pada ikan nila saat proses reproduksi berlangsung (Safir et al., 2017). Berbeda halnya dengan ikan $P$. kauderni induk betina, kembali pada kondisi dalam siklus yang normal yakni berenang mencari makan dan kembali memasuki fase reproduksi (Gunawan et al., 2010). Jika ikan $P$. kauderni induk betina melakukan pemijahan dengan ikan $P$. kauderni induk jantan sesaat setelah proses penyapihan berakhir tentunya akan menyebabkan kualitas benih yang rendah untuk jangka panjang. Oleh karena itu, upaya yang dapat dilakukan dalam meningkatkan kualitas dan kuantitas dari ikan $P$. kauderni salah satunya melalui peningkatan jumlah populasi jantan. Salah satu cara untuk menghasilkan ikan berjenis kelamin jantan yakni melalui kegiatan seks reversal (Safir et al., 2017; Safir et al., 2020a; Safir et al., 2020b).

Seks reversal adalah metode pengarahan pembentukan jenis kelamin pada ikan menjadi jantan secara fenotipe (secara fisik seperti bentuk/ukuran tubuh namun tidak merubah secara genetiknya) dengan menggunakan hormon, seperti hormon 17amethyltestosteron (Safir et al., 2017; Safir et al., 2020a; Safir et al., 2020b; Safir et al., 2020c). Penelitian terkait pengarahan jenis kelamin pada ikan $P$. kauderni tergolong baru 
khususnya dengan menggunakan hormon sintetik seperti $17 \alpha$ - methyltestosteron (17aMT) dengan metode perendaman. Berdasarkan uraian tersebut, penelitian ini dilakukan untuk mendapatkan dosis hormon 17a-MT yang terbaik dalam menghasilkan persentase yang tinggi pada ikan $P$. kauderni jantan.

\section{Metode Penelitian}

\section{Waktu dan Tempat}

Penelitian dilakukan mulai Januari sampai dengan Februari 2020, bertempat di Balai Pelatihan Budidaya dan Konservasi Laut (BPBKL), Desa Bone Baru, Kecamatan Banggai Utara, Kabupaten Banggai Laut, Sulawesi Tengah.

\section{Organisme dan Bahan Uji}

Larva $P$. kauderni yang digunakan berumur \pm 21 hari pasca tetas. Larva diperoleh dari penetasan induk ikan $P$. kauderni hasil penangkapan dari perairan Bone Baru, Kecamatan banggai Utara, Kabupaten Banggai yang juga merupakan areal penelitian. Induk yang ditangkap dicirikan dengan adanya telur yang dierami (belum menetas) dalam mulutnya, selanjutnya dimasukkan dalam bak fiber bulat (diameter $100 \mathrm{~cm}$ dan tinggi 100 $\mathrm{cm}$ ) yang berisikan air \pm 500 liter. Dalam bak penetasan, dilengkapi dengan selang dan batu aerasi yang terhubung dengan aerator sebagai penyuplai oksigen serta diberi sebanyak 5 ekor bulu babi (Diadema setosum). Setelah larva mencapai umur 21 hari (3 hari pasca pelepasan dari mulut induknya) selanjutnya dipisahkan dari induknya dengan cara memindahkan larva ke wadah yang telah dipersiapkan. Seluruh larva digabungkan menjadi satu dalam wadah (bak fiber berukuran $100 \times 60 \times 40 \mathrm{~cm}^{3}$ ). Sebelum larva digunakan, terlebih dahulu diadaptasikan dengan baik sesuai metode yang dilakukan oleh Safir et al (2020a); Safir et al (2020b) .

Hormon 17a-methyltestosteron dengan merek dagan Argent, Philippines dimasukkan dalam Microcentrifuge Tube 0,5 mL sesuai dengan dosis perlakuan. Selanjutnya setiap Microcentrifuge Tube ditambahkan etanol $100 \%$ sebanyak $0,25 \mathrm{~mL}$ dan dikocok hingga tidak terlihat perbedaan antara hormon dengan etanol.

\section{Desain Penelitian}

Penelitian menggunakan Rancangan Acak Lengkap (RAL) yang terdiri atas empat dosis perlakuan perendaman larva dengan hormon 17a-methyltestosteron. Dosis perendaman tersebut yakni $0 \mathrm{mg} / \mathrm{L} ; 2 \mathrm{mg} / \mathrm{L} ; 4 \mathrm{mg} / \mathrm{L}$; dan $6 \mathrm{mg} / \mathrm{L}$ air. Lama waktu perendaman setiap perlakuan adalah 4 jam. Setiap perlakuan diberi empat kali ulangan.

\section{Pelaksanaan Seks Reversal}

Metode pelaksanaan seks reversal mengacu pada penelitian Safir et al (2017). Masing-masing sebanyak 10 ekor larva ikan $P$. kauderni umur \pm 21 hari pasca tetas yang telah dicatat bobot awalnya, dimasukkan dalam kantong plastik bervolume 2,5 liter yang 
telah diisi dengan 1 liter air laut bersalinitas 35 ppt dan larutan hormon sesuai perlakuan. Selanjutnya diberi oksigen dengan perbandingan yang sama dengan air (1:1), dan diikat kuat menggunakan karet, didiamkan pada suhu ruang $\left( \pm 27^{\circ} \mathrm{C}\right)$ selama 4 jam. Selanjutnya larva dikeluarkan dari kantongan (dipisahkan antara air dan larva menggunakan serokan), kemudian dicelupkan dalam air bersih (air laut bersalinitas 35 ppt) yang telah dipersiapkan. Air dalam wadah sebagai tempat pembilasan dilakukan pergantian setiap ulangan untuk semua perlakuan. Setelah itu, dimasukkan dalam wadah pemeliharaan (akuarium berukuran $15 \times 20 \times 20 \mathrm{~cm}^{3}$ ) yang telah diisi air dengan volume 4 liter dan telah diberi batu aerasi yang terhubung dengan aerator sebagi penyuplai oksigen pada media pemeliharaan. Selain itu, setiap wadah pemeliharaan juga dilengkapi dengan satu ekor bulu babi ( $D$. setosum) sesuai dengan mikrohabitat dari ikan $P$. kauderni (Rahman \& Safir, 2018). Air hasil perendaman larva yang mengandung hormon 17a-MT, dibuang pada lubang tanah yang telah dipersiapkan untuk menghindari dampak negatif pada lingkungan (Safir et al., 2017; Safir et al., 2020c).

\section{Pemeliharaan Organisme Uji}

Pemberian pakan (Artemia sp.) pada organisme uji dilakukan dua jam setelah berada di dalam wadah pemeliharaan. Frekuensi pemberian pakan 4 kali dalam sehari secara ad-satiation (Safir et al., 2020a; Safir et al., 2020b; Safir et al., 2020c). Pemeliharaan dilakukan selama 30 hari dan setiap 10 hari dilakukan penimbangan bobot tubuh total dari organisme uji pada setiap ulangan untuk semua perlakuan. Pada akhir pemeliharaan, sebanyak tiga ekor organisme uji diambil dari setiap ulangan untuk semua perlakuan guna pengamatan jenis kelamin. Agar kualitas air tetap berada pada kisaran yang sesuai dengan kebutuhan organisme uji maka dalam pemeliharaan diterapkan sistem resirkulasi semi tertutup. Pemantauan kualitas dan penggantian air serta pembersihan penyaring dalam bak tandon (bak penampung dan penyalur air) dilakukan dua kali dalam seminggu hingga akhir pemeliharaan. Selanjutnya, untuk pengukuran parameter kualitas air meliputi $\mathrm{pH}$, oksigen terlarut, suhu serta salinitas, dilakukan setiap hari (pagi, siang, dan sore hari) secara berkala.

\section{Parameter Pengamatan}

Parameter organisme uji yang diamati untuk melihat pengaruh semua perlakuan meliputi, laju pertumbuhan harian (LPH), pertambahan biomasa total (PBT), rasio kelamin jantan, dan kelangsungan hidup $(\mathrm{KH})$. Metode dan persamaan yang digunakan dalam menghitung LPH dan PBT mengacu pada penelitian Safir (2018). Selanjutnya, untuk rasio kelamin jantan dan betina mengacu pada penelitian Chakraborty et al., (2011), dan Safir et al., (2017). Kelangsungan hidup dihitung dengan membandingkan antara organisme uji pada akhir dan awal pemeliharaan dikali dengan 100. 
Analisa Data

Semua data yang diperoleh ditabulasi menggunakan miscrosoft excel 2017. Data rasio kelamin jantan, $\mathrm{LPH}, \mathrm{PBT}$, dan $\mathrm{KH}$ dianalisis dengan uji one-way ANOVA. Apabila terdapat pengaruh dari perlakuan maka dilakukan uji lanjut Duncan.

\section{Hasil dan Pembahasan}

\section{Rasio Kelamin Jantan}

Rasio kelamin (jantan dan betina) dari organisme uji pada hari ke 30 pasca perendaman hormon 17a-methyltestosteron dengan dosis berbeda ditampilkan pada Tabel 1. Hasil analisis menunjukkan persentase rasio jantan dari nilai rendah ketinggi secara berurut terjadi pada perlakuan hormon 17a-methyltestosteron dengan dosis 6 mg/L (50,00\%), 0 mg/L (66,67\%), 4 mg/L (75,00\%) dan 2 mg/L air (91,67\%). Hasil uji lanjut menunjukkan semua perlakuan tidak menunjukkan perbedaan dengan kontrol $(P>0,05)$, namun rasio jantan pada perlakuan $17 \alpha$-methyltestosteron dosis $2 \mathrm{mg} / \mathrm{L}$ air lebih tinggi dibandingkan perlakuan dosis $6 \mathrm{mg} / \mathrm{L}$ air $(P<0,05)$.

Rasio kelamin jantan yang tinggi pada perlakuan 17a-methyltestosteron dosis 2 $\mathrm{mg} / \mathrm{L}$ air diduga dosis tersebut mendekati dosis yang sesuai dalam penghambatan aktivitas aromatase dalam pembentukan hormon estrogen. Arfah et al., (2013) mengemukakan bahwa pengaplikasian bahan penghambat kinerja aromatese guna meningkatkan persentase ikan jantan dapat diperoleh dengan pengaplikasian dosis yang tepat. Sebaliknya, pengaplikasian dosis yang berlebih akan memberiakan umpan balik pada ikan uji, dan menghasilkan ikan betina seperti yang terjadi pada ikan lele (Ictalurus punctatus) (Bhandar et al., 2004) dan ikan cupang (Betta splendens) (Arfah et al., 2013). Lebih lanjut dikemukakan Arfah et al., (2013) bahwa hal tersebut terjadi dikarenakan adanya suatu zat di dalam tubuh organisme yang serupa dengan aromatase, ketika kadar hormon 17a-methyltestosteron tinggi masuk ke dalam tubuh, zat (serupa dengan aromatase) akan merubah hormon $17 \alpha$-methyltestosteron menjadi estradiol-17 $\beta$ dan sekaligus berperan sebagaimana hormon estradiol-17 $\beta$ yang merangsang dalam pembentukan gonad betina ikan uji.

Mekanisme kerja dari hormon 17a-methyltestosteron dalam pengerahan jenis kelamin secara fenotip yakni melibatkan aromatase dimana aktivitas dari enzime tersebut dihambat dalam menghasilkan hormon estrogen dari androgen, dan pada akhirnya persentase androgen lebih tinggi (Kwon et al., 2000; Kobayashi \& Nagahama, 2009; Safir et al., 2017; Safir et al., 2020a; Safir et al., 2020b). 
Tabel 1. Rasio jantan dan betina ikan $P$. kauderni pada akhir penelitian

\begin{tabular}{cccccc}
\hline Perlakuan dosis & $\mathbf{N}^{*}$ & $\delta$ & $q$ & $\% \sigma^{\Uparrow}$ & $\% \%$ \\
\hline $0 \mathrm{mg} / \mathrm{L}$ & 12 & 8 & 4 & $66,67 \pm 27,22^{\mathrm{ab}}$ & $33,33 \pm 27,22^{\mathrm{ab}}$ \\
$2 \mathrm{mg} / \mathrm{L}$ & 12 & 11 & 1 & $91,67 \pm 16,67^{\mathrm{b}}$ & $8,33 \pm 16,67^{\mathrm{b}}$ \\
$4 \mathrm{mg} / \mathrm{L}$ & 12 & 9 & 3 & $75,00 \pm 19,25^{\mathrm{ab}}$ & $24,99 \pm 19,25^{\mathrm{ab}}$ \\
$6 \mathrm{mg} / \mathrm{L}$ & 12 & 6 & 6 & $50,00 \pm 23,96^{\mathrm{a}}$ & $50,00 \pm 23,96^{\mathrm{a}}$ \\
\hline
\end{tabular}

Keterangan: *Jumlah organisme yang diamati 3 ekor dari 10 ekor untuk setiap ulangan

\section{Laju Pertumbuhan Harian dan Pertambahan Biomasa Total}

Laju pertubuhan harian organisme uji untuk setiap perlakuan hormon 17amethyltestosteron tidak memberikan pengaruh yang berbeda $(P>0,05)($ Gambar 1$)$.

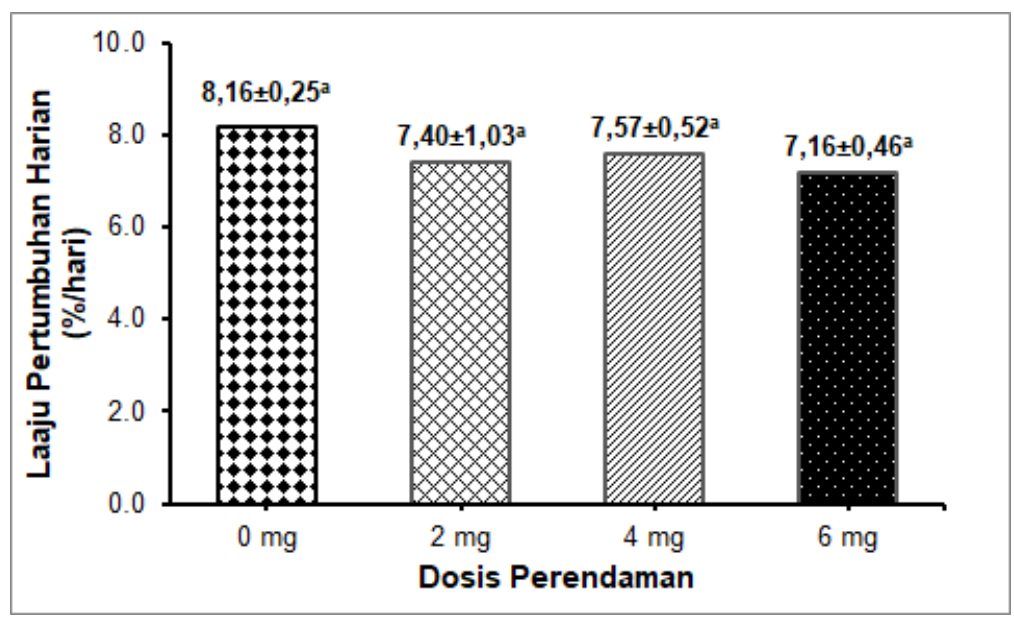

Gambar 1. Laju pertumbuhan harian ikan $P$. kauderni yang diberi hormon $17 \alpha$-methyltestosteron dengan lama pemeliharaan 30 hari

Hasil yang diperoleh dalam penelitian ini serupa yang telah dilaporkan dari penelitian sebelumnya dimana perlakuan 17a-methyltestosteron melalui perendaman Artemia sp. sebagai pakan (Safir et al., 2020b) dan melalui perendaman kombinasi suhu (Safir et al., 2020a) dengan lama pemeliharaan 30 hari, tidak menunjukkan pengaruh pada laju pertumbuhan harian ikan $P$. kauderni. Lebih lanjut dikemukakan oleh Celik et al., (2011), dan Safir et al., (2017) bahwa efek anabolik (peningkatan pertumbuhan) dari hormon 17a-methyltestosteron akan terlihat setelah organisme uji mengalami kematangan gonad seperti yang tserjadi pada ikan nila. Selanjutnya, pertambahan biomasa total untuk semua perlakuan tidak berbeda dengan kontrol kecuali perlakuan dosis $6 \mathrm{mg} / \mathrm{L}$ air. Dimana pertambahan biomasa total pada perlakuan hormon 17amethyltestosteron dengan dosis $6 \mathrm{mg} / \mathrm{L}$ lebih rendah dibandingkan kontrol, sedangkan antar perlakuan tidak berbeda nyata (Gambar 2). 


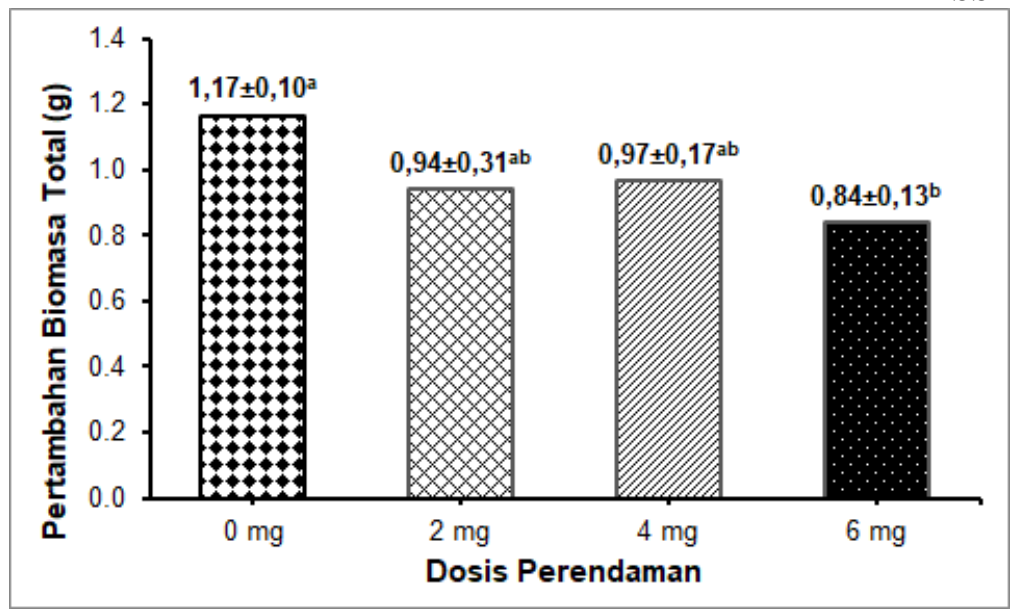

ISSN 2354-7251 (print)

Gambar 2. Pertambahan biomasa total dari organisme uji pada akhir penelitian

Pertambahan biomasa total yang rendah pada perlakuan perendaman hormon $17 \alpha$-methyltestosteron pada dosis $6 \mathrm{mg} / \mathrm{L}$ diduga terkait nilai kelangsungan hidup yang lebih rendah $(57,5 \%)$ (Gambar 3). Pertambahan biomasa total diperoleh dengan cara menghitung selisih antara bobot total dari semua ikan yang hidup pada akhir dan awal pemeliharaan. Sejalan yang dilaporakan pada penelitian sebelumnya bahwa nilai pertambahan biomasa total menjadi rendah, jika jumlah organisme yang hidup pada akhir pemeliharaan lebih rendah dan laju pertumbuhan yang dihasilkan adalah sama (Safir et al., 2020c).

\section{Kelangsungan Hidup}

Kelangsungan hidup organisme uji hingga akhir pemeliharaan berkisar antara $57,5 \%-80,0 \%$ (Gambar 3.). Hasil analisis menunjukkan bahwa kelangsungan hidup organisme uji untuk semua perlakuan tidak berbeda dengan kontrol $(P>0,05)$ kecuali perlakuan hormon 17a-methyltestosteron dengan dosis $6 \mathrm{mg} / \mathrm{L}$ air yang persentasenya lebih rendah $(57,5 \%)$.

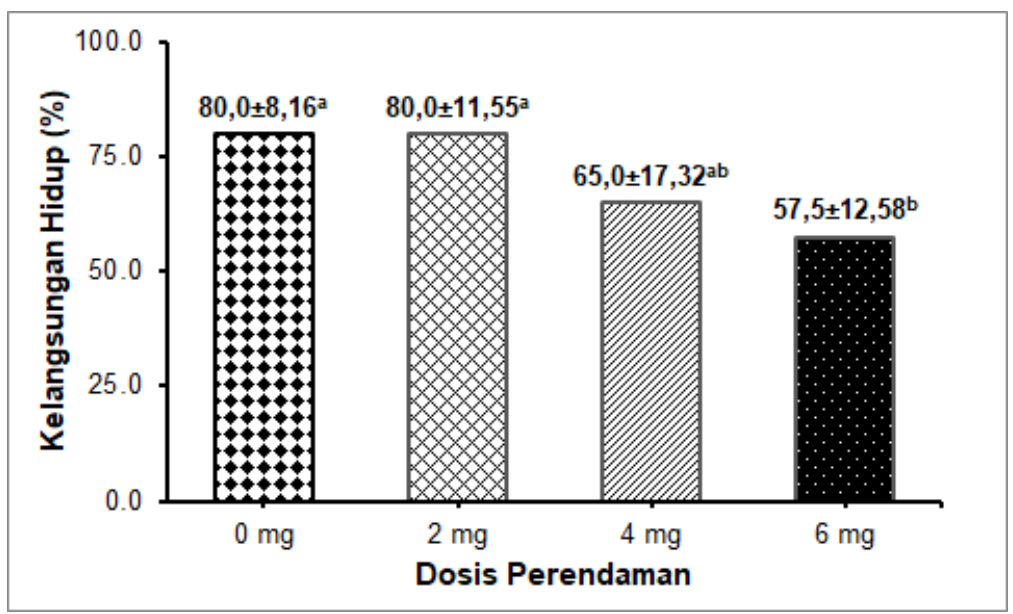

Gambar 3. Kelangsungan hidup organisme uji pada akhir pemeliharaan. 
Hasil yang bebeda yang dilaporkan oleh beberapa peneliti diantaranya Afpriyaningrum et al., (2016), dan Safir et al., (2017) pada ikan nila, serta (Safir et al., 2020b) pada ikan P. kauderni, dimana perlakuan seks reversal dengan hormon 17amethyltestosteron tidak memberikan pengaruh terhadap tingkat kelangsungan hidup dari ikan perlakuan. Kelangsungan hidup yang rendah dalam penelitian ini diduga penggunaan dosis hormon $17 \alpha$-methyltestosteron terlalu tinggi. Hal ini diduga ikan $P$. kauderni tergolong ikan yang sensitif terhadap senyawa organik sintetik, sehingga dosis yang tinggi akan menyebabkan metabolisme dalam tubuh ikan uji terganggu dan pada akhirnya menyebabkan kematian (Connell \& Miller, 2006; Bustaman et al., 2009). Selanjutnya untuk parameter kualitas air selama pemeliharaan seperti $\mathrm{pH}(7,4-8,14)$, oksigen terlarut $(4-8,2 \mathrm{mg} / \mathrm{L})$, suhu $\left(25-28^{\circ} \mathrm{C}\right)$ dan salinitas $(27-39 \mathrm{~g} / \mathrm{L})$, masih berada pada kisaran yang sesuai untuk pemeliharaan ikan P. kauderni (Gunawan et al., 2010; Safir et al., 2020a; Safir et al., 2020b; Safir et al., 2020c) dan bukan merupakan penyebab rendahnya kelangsungan hidup pada perlakuan.

\section{Kesimpulan}

Dosis hormon 17a- methyltestosteron pada larva $P$. kauderni umur 21 hari berpengaruh terhadap peningkatan persentase rasio kelamin jantan ikan $P$. kauderni, dimana dosis terbaik adalah $2 \mathrm{mg} / \mathrm{L}$ air.

\section{Daftar Pustaka}

Afpriyaningrum, M., Soelistyowati, D., Alimuddin, Zairin, J. M., Setiawati, M., \& Hardiantho, D. (2016). Maskulinisasi Ikan Nila Melalui Perendaman Larva pada Suhu $36{ }^{\circ} \mathrm{C}$ dan Kadar Residu 17a-metiltestosteron dalam Tubuh Ikan. OmniAkuatika, $12(3)$

106-113. https://doi.org/http://dx.doi.org/10.20884/1.oa.2016.12.3.132

Arfah, H., Soelistyowati, D. T., \& Bulkini, A. (2013). Maskulinisasi Ikan Cupang Betta Splendens Melalui Perendaman Embrio dalam Ekstrak Purwoceng Pimpinella alpina. Jurnal Akuakultur Indonesia, 12(2), 144-149. https://doi.org/10.19027/jai.12.144-149

Bhandar, R. K., Komuro, H., Higa, M., \& Nakamura, M. (2004). Sex Inversion of Sexually Immature Honeycomb Grouper (Ephinephelus merra) by Aromatase Inhibitor. Zoological Sciense, 21(3), 305-310. https://doi.org/10.2108/zsj.21.305

Bustaman, W. J., Arisandi, A., \& Abida, I. W. (2009). Efektivitas Hormon 17amethyltestosteron untuk Memanipulasi Kelamin Ikan Nila (Oreochromis niloticus) pada Pemeliharaan Salinitas yang Berbeda. Jurnal Kelautan, 2(1), 57-65. https://doi.org/https://doi.org/10.21107/jk.v2i1.903

Carlos, N. S. T., Rondonuwu, A. B., \& Watung, V. N. R. (2014). Distribusi dan Kelimpahan Pterapogon kauderni Koumans, 1933 (Apogonidae) di Selat Lembeh Bagian Timur, Kota Bitung. Jurnal Ilmiah Platax, 2(3), 121-126. https://doi.org/10.35800/jip.2.3.2014.9124 
Celik, I., Guner, Y., \& Celik, P. (2011). Effect of Orally-Administered 17amethyltestosterone at Different Doses on the Sex Reversal of the Nile Tilapia (Oreochromis niloticus, Linneaus 1758). Journal of Animal and Veterinary Advances, 10(7), 853-857. https://doi.org/10.3923/javaa.2011.853.857

Chakraborty, S. B., Mazumdar, D., Chatterji, U., \& Banerjee, S. (2011). Growth of MixedSex and Monosex Nile Tilapia in Different Culture Systems. Turkish Journal of Fisheries and Aquatic Sciences, 11, 133-138. https://doi.org/10.4194/trjfas.2011.0117

Connell, D. W., \& Miller, G. J. (2006). Kimia dan Ekotoksikologi Pencemaran Penerjemah: Yanti Koestoer. Judul Asli: Chemistry and Ecotoxicology of Pollution. Tahun 1995. Jakarta: UI Press.

Gunawan, Hupatea, J. H., \& Setiawati, K. M. (2010). Pemeliharaan Induk Ikan Capungan Banggai (Pterapogon kauderni) dengan Kepadatan yang Berbeda. Prosiding Forum Inovasi Teknologi Akuakultur, 461-466.

Kobayashi, T., \& Nagahama, Y. (2009). Molecular Aspects of Gonadal Differentiation in a Teleost Fish, the Nile Tilapia. Sexual Development, 3(2-3), 108-117. https://doi.org/https://doi.org/10.1159/000223076

Kwon, J. Y., Haghpanah, V., Kogson-Hurtado, L. M., Mcandrew, B. J., \& Penman, D. J. (2000). Masculinization of Genetic Female Nile Tilapia (Oreochromis niloticus) by Dietary Administration of an Aromatase Inhibitor During Sexual Differentiation. Journal of Experimental Zoology, 287(1), 46-53. https://doi.org/10.1002/1097010X(20000615)287:13.0.CO;2-X

Ndobe, S., Moore, A., Salanggon, A. I. M., Setyohadi, D., Herawati, E. Y., \& Soemarno. (2013a). Pengelolaan Banggai Cardinalfish (Pterapogon kauderni) melalui Konsep Ecosystem-Based Approach. Marine Fisheries, 4(2), 115-126. https://doi.org/https://doi.org/10.29244/jmf.4.2.115-126

Ndobe, S., Widiastuti, I., \& Moore, A. (2013b). Sex Ratio and Predation on Recruits in the Marine Ornamental Banggai Cardinalfish (Pterapogon kauderni). Konferensi Akuakultur Indonesia 2013. Sulawesi Tengah, 9-20.

Rahman, S. A., \& Safir, M. (2018). Performa Pertumbuhan dan Kelangsungan Hidup Ikan Capungan Banggai (Pterapogon kauderni) pada Mikrohabitat yang Berbeda. Octopus: Jurnal Ilmu Perikanan, 7(2), 1-6. https://doi.org/https://doi.org/10.26618/octopus.v7i2.2462

Safir, M. (2018). Respon Fisiologis dan Biokimia Ikan Nila Hasil Sex Reversal, Diberi Pakan Kadar Protein Berbeda dan Diperkaya dengan Hormon Pertumbuhan. Disertasi Pascasarjana. Institut Pertanian Bogor, Bogor.

Safir, M., Aminuddin, Setiawati, M., Zairin, Jr. M., \& Suprayudi, M. A. (2017). Growth Performance of Nile Tilapia Immersed in 17a-methyltestosterone and $\mathrm{rE} / \mathrm{GH}$, and Fed a Diet Enriched with rEIGH. Omni-Akuatika, 13(2), 57-64. https://doi.org/http://dx.doi.org/10.20884/1.oa.2017.13.2.288

Safir, M., Rukka, A. H., Mangitung, S. F., \& Sambaeni, D. (2020a). Pengaruh Perendaman Hormon 17a-Methyltestosteron dan Suhu yang Berbeda Terhadap Persentase Kelamin Jantan dan Performa Pertumbuhan Ikan Banggai Cardinal (Pterapogon kauderni). Octopus: Jurnal Ilmu Perikanan, 9(2), 1-9. 
ISSN 2354-7251 (print)

Safir, M., Tobigo, D. T., Mangitung, S. F., Madinawati, \& Zainab. (2020b). Masculinization of Banggai Cardinalfish (Pterapogon kauderni) using 17a-Methyltestosteroneenriched Artemia sp. Omni-Akuatika, 16(2), 135-140. https://doi.org/10.20884/1.oa.2020.16.2.809

Safir, M., Tobigo, D. T., Mangitung, S. F., Sambaeni, D., Ryaldi, M., Adam, R. D., Husain. (2020c). Tingkat Kelangsungan Hidup dan Pertumbuhan Larva Pterapogon kauderni yang Diberi Jenis Pakan Berbeda. Jurnal Agrisains, 21(1), 1-7.

Sugama, K. (2008). Pemiljahan dan pembesaran anak ikan kardinal banggai (Pterapogon kauderni). Jurnal Riset Akuakultur, 3(1), 83-90. https://doi.org/http://dx.doi.org/10.15578/jra.3.1.2008.83-90 